\title{
Human pulmonary dirofilariasis: atypical presentation of a rare disease
}

\author{
Dirofilariose pulmonar humana: apresentação atípica \\ de uma doença rara
}
Ricardo Jorge Vital' ${ }^{1}$, Leandro Accardo de Mattos $^{1}$ and Gustavo Souza Portes Meirelles ${ }^{1,2}$

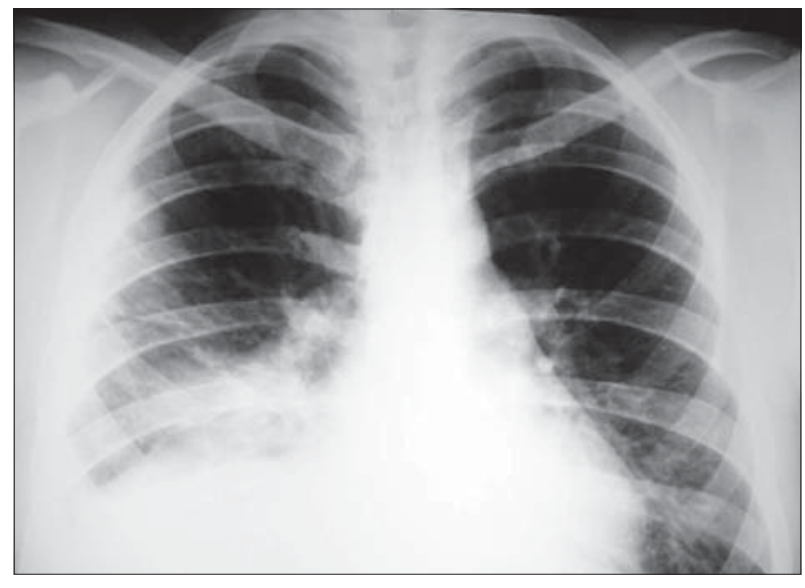

A

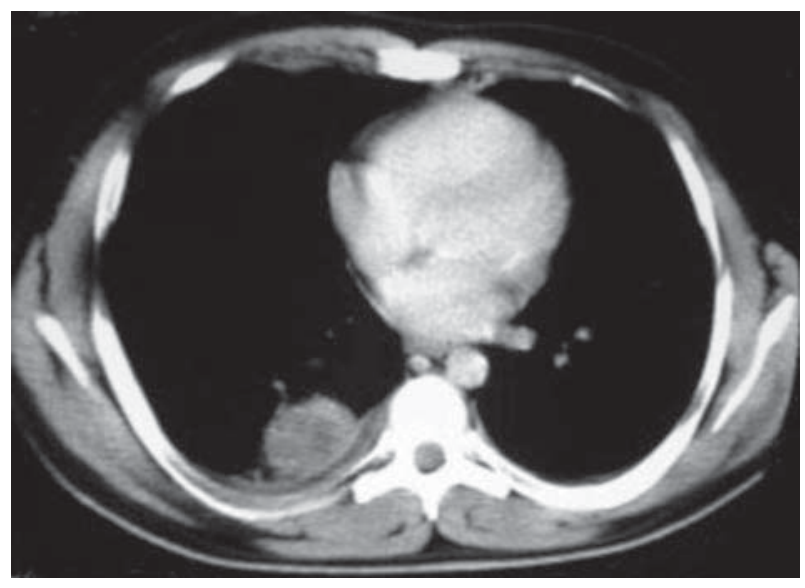

B

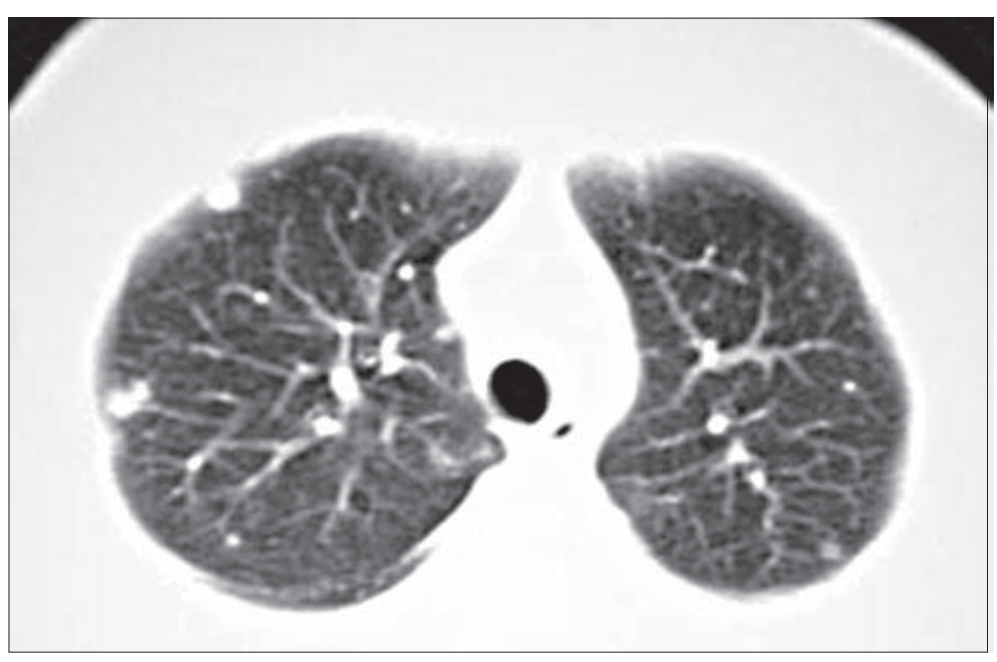

C

\footnotetext{
1. Departamento de Diagnóstico por Imagem da Escola Paulista de Medicina da Universidade Federal de São Paulo, São Paulo, SP. 2. Centro de Medicina Diagnóstica Fleury, São Paulo, SP.

Address to: Dr. Ricardo Jorge Vital. Deptº de Diagnóstico por Imagem/UNIFESP/EPM. R. Napoleão de Barros 800, Vila Clementino, 04024-001 São Paulo, SP. e-mail: rjvital@gmail.com

Recebido para publicação em 22/4/2005

Aceito em 23/11/2005
} 
Twenty-year-old male was admitted to hospital with a 15-day history of thoracic pain, dyspnea and fever. He was submitted to a chest radiograph (Figure A) and a computed tomography (Figures $\mathrm{B}$ and $\mathrm{C}$ ), which revealed right pleural effusion and multiple bilateral pulmonary nodules. After empiric treatment for pneumonia, with antibiotics, his symptoms improved, but the radiological findings remained the same. A biopsy was performed, defining the diagnosis as dirofilariasis. The patient later reported that, during his holidays at the beach, his neighbor's dog had died from that very illness. Pulmonary dirofilariasis is common in dogs and is caused by the nematode Dirofilaria immitis. When dogs are bitten by infected mosquites, these suck the microfilarias out of the infected dogs and later transmit them to the human host. The clinical presentation of multiple pulmonary nodules is unusual, occurring only in about $25 \%$ of cases. Bilateral lung involvement is infrequent, and presents in $12.5 \%$ of patients, with or without associated pleural effusion.

0 paciente, de 20 anos de idade, apresentava dor torácica, dispnéia e febre de início há 15 dias, quando foi admitido no hospital. A radiografia simples do tórax (Figura A) e tomografia computadorizada (Figuras B e C) evidenciaram derrame pleural à direita e múltiplos nódulos pulmonares bilaterais. Após o tratamento empírico para pneumonia, com antibióticos, houve melhora dos sintomas, mas os achados radiológicos persistiram inalterados. Optou-se pela realização de biópsia pulmonar, que definiu o diagnóstico de dirofilariose. 0 paciente lembrou-se então de que, durante viagem ao litoral, fora informado por seu vizinho da morte de seu cão com a mesma doença. A dirofilariose pulmonar é comum em cães e é causada pelo nematódeo Dirofilaria immitis. Quando os cães são picados por mosquitos infectados, estes sugam as microfilárias e as transmitem ao homem. A apresentação clínica na forma de múltiplos nódulos pulmonares não é freqüiente, ocorrendo em cerca de $25 \%$ dos casos. 0 acometimento pulmonar bilateral também não é usual, ocorrendo em 12,5\% dos pacientes, associado ou não a derrame pleural.

\section{REFERENCES}

1. Campos JRM, Barbas CS, Filomeno LT. Human pulmonary dirofilariasis. Analysis of 24 cases from São Paulo, Brazil. Chest 112: 729-733, 1997.

2. Oshiro Y, Murayama S, Sunagawa U. Pulmonary dirofilariasis: computed tomography findings and correlation with pathologic features. The Journal of Computed Assisted Tomography 28: 796-800, 2004.

3. Wand A, Kasirajan LP, Sridhar S. Solitary pulmonary nodule due to dirofilariasis. Journal of Thoracic Imaging 15: 198-200, 2000. 